\title{
An assessment of the concentrations of PCDDs/Fs in contaminated bottom sediments and their sources and ecological risk
}

\author{
Agnieszka Baran ${ }^{1}$ (1) $\cdot$ Monika Mierzwa-Hersztek ${ }^{1} \cdot$ Magdalena Urbaniak $^{2} \cdot$ Krzysztof Gondek $^{1} \cdot$ Marek Tarnawski $^{3}$. \\ Magdalena Szara ${ }^{1} \cdot$ Marek Zieliński $^{4}$
}

Received: 27 May 2019 / Accepted: 8 October 2019 / Published online: 14 November 2019

(C) The Author(s) 2019

\begin{abstract}
Purpose The purpose of the study was to determine the levels of polychlorinated dibenzo- $p$-dioxin and polychlorinated dibenzofuran $(\mathrm{PCDD} / \mathrm{F})$, two types of persistent organic pollutant (POP), in an urban retention reservoir located in an industrial zone within a coal-mining region. It also assesses the potential ecological risk of the PCDDs/Fs present in bottom sediments and the relationship between their content and the fraction of organic matter.

Materials and methods The sediment samples were collected from Rybnik Reservoir, located in the centre of the Rybnik Coal Region, Silesia, one of Poland's major industrial centres. Seventeen PCDD/F congeners in the surface of the sediments were analysed using high-resolution gas chromatography and high-resolution mass spectrometry (HRGC/HRMS).

Results and discussion The toxic equivalency (TEQ) of the PCDDs/Fs in the sediments ranged from 1.65 to $32.68 \mathrm{pg}$ TEQ $\mathrm{g}^{-1}$. PCDDs constituted 59-78\% of the total PCDDs/Fs, while the PCDFs accounted for $22-41 \%$. The pattern of PCDD/F congeners in the sediments was dominated by OCDD. However, the second-most prevalent constituents were OCDF and $\sum \mathrm{HpCDFs}$ in the low TOC sediment $\left(<10 \mathrm{~g} \mathrm{TOC} \mathrm{kg}^{-1}\right)$, but HpCDD in the rich TOC samples $\left(>10 \mathrm{~g} \mathrm{TOC} \mathrm{kg}^{-1}\right)$. PCDD/F concentrations in the sediment samples were 2- to 38-fold higher than the sediment quality guidelines limit, indicating high ecological risk potential. Although a considerable proportion of PCDDs/Fs in the bottom sediments from the Rybnik Reservoir were derived from combustion processes, they were also obtained via transport, wastewater discharge, high-temperature processes and thermal electricity generation. The PCDD/F concentrations were significantly correlated with all fractions of organic matter; however, the strongest correlation coefficients were found between PCDDs/Fs and humic substances. Besides organic matter, the proportions of silt/clay fractions within sediments played an important role in the transport of PCDDs/Fs in bottom sediments.

Conclusions The silt/clay fraction of the bottom sediments plays a dominant role in the movement of PCDDs/Fs, while the organic matter fraction affects their sorption. The results indicate that the environmental behaviour of PCDDs/Fs is affected by the quantity and quality of organic matter and the texture of sediments.
\end{abstract}

Keywords Bottom sediments $\cdot$ PCDDs/Fs · Anthropogenic sources · Ecological assessment · Organic matter $\cdot$ Partial size

Responsible editor: Jasmina Obhodas

Agnieszka Baran

Agnieszka.Baran@urk.edu.pl

1 Department of Agricultural and Environmental Chemistry, University of Agriculture in Krakow, Krakow, Poland

2 European Regional Centre for Ecohydrology of the Polish Academy of Sciences, Tylna 3, 90-364, Lodz, Poland

3 Department of Hydraulic Engineering and Geotechnics, University of Agriculture in Krakow, Krakow, Poland

4 Nofer Institute of Occupational Medicine, Teresy 8, 91-348, Lodz, Poland

\section{Introduction}

Polychlorinated dibenzo- $p$-dioxins and polychlorinated dibenzofurans (PCDDs/Fs) are both examples of persistent organic pollutants (POPs) (Lee et al. 2006; Li et al. 2012; Lewandowski et al. 2014; Förstner et al. 2016; Louchouarn et al. 2018). The persistence and hydrophobicity of PCDDs/Fs and their resistance to degradation make them a significant ecotoxicological problem, one that is difficult to control (Nieuwoudt et al. 2009; Roumak et al. 2018). In dammed reservoirs, PCDDs/Fs may be subject to sedimentation and adsorption on suspended particles and deposition in the form of organic matter sediments, which may further act as a source 
of secondary contamination (Nie et al. 2013). PCDDs/Fs demonstrate good stability in a water environment; this has been attributed to their low solubility and thus strong adsorption on organic matter particles and lipids, which results in up to $97 \%$ of emitted PCDDs/Fs being deposited in sediments. Moreover, due to their high octanol-water partition confections ( $\log K_{\text {ow }} 4-8$ ), PCDDs/Fs undergo bioaccumulation in sediment-dwelling organisms and biomagnification in both aquatic and terrestrial food chains (Lee et al. 2006; Micheletti et al. 2007; Nunes et al. 2011; Nie et al. 2013; Urbaniak et al. 2014; Förstner et al. 2016; Roumak et al. 2018). Consequently, the determination of PCDD/F concentrations in bottom sediments plays an important part in determining their ecological risk and human exposure (Micheletti et al. 2007; Li et al. 2012). The precise qualitative and quantitative composition of organic matter, including humus substances, soluble organic matter and black carbon fractions, is believed to be a key element in determining potential PCDD/F accumulation in bottom sediments (Perminova et al. 2006, 2019; Ghosh 2007).

The aims of the study were threefold: (1) to evaluate the concentration and distribution of PCDDs/Fs in bottom sediments from the Rybnik Reservoir; (2) to assess their sources and the potential ecological risk in sediments; and (3) to investigate the relationship between the fraction of organic matter and the content of the compounds of interest in bottom sediments.

\section{Materials and methods}

\subsection{Reservoir characteristics and bottom sediment sampling}

The Rybnik Reservoir $\left(50^{\circ} 8^{\prime} 26 \mathrm{~N}, 18^{\circ} 29^{\prime} 51 \mathrm{E}\right)$ is one of the largest water reservoirs located in Silesia in the south-western part of Poland (Fig. 1). The regular capacity of the reservoir is 22.5 million $\mathrm{m}^{3}$, with 1.5 million $\mathrm{m}^{3}$ of reserve capacity. The region in which the reservoir is located is highly industrialised, with mining (hard coal), metallurgical (steel and colour metal mills), construction, transport and chemical industries. Moreover, the Rybnik Reservoir plays an important technological role, as heated waters from the "Rybnik" Power Plant are discharged and sourced from the reservoir (Kostecki et al. 2017; Baran et al. 2019). The predominant subcatchment, in the southern part of the drainage area, consists of urbanised areas or areas characterised by scattered rural development, as well as agricultural areas. The northern part consists of forest areas. The Ruda River, on which the

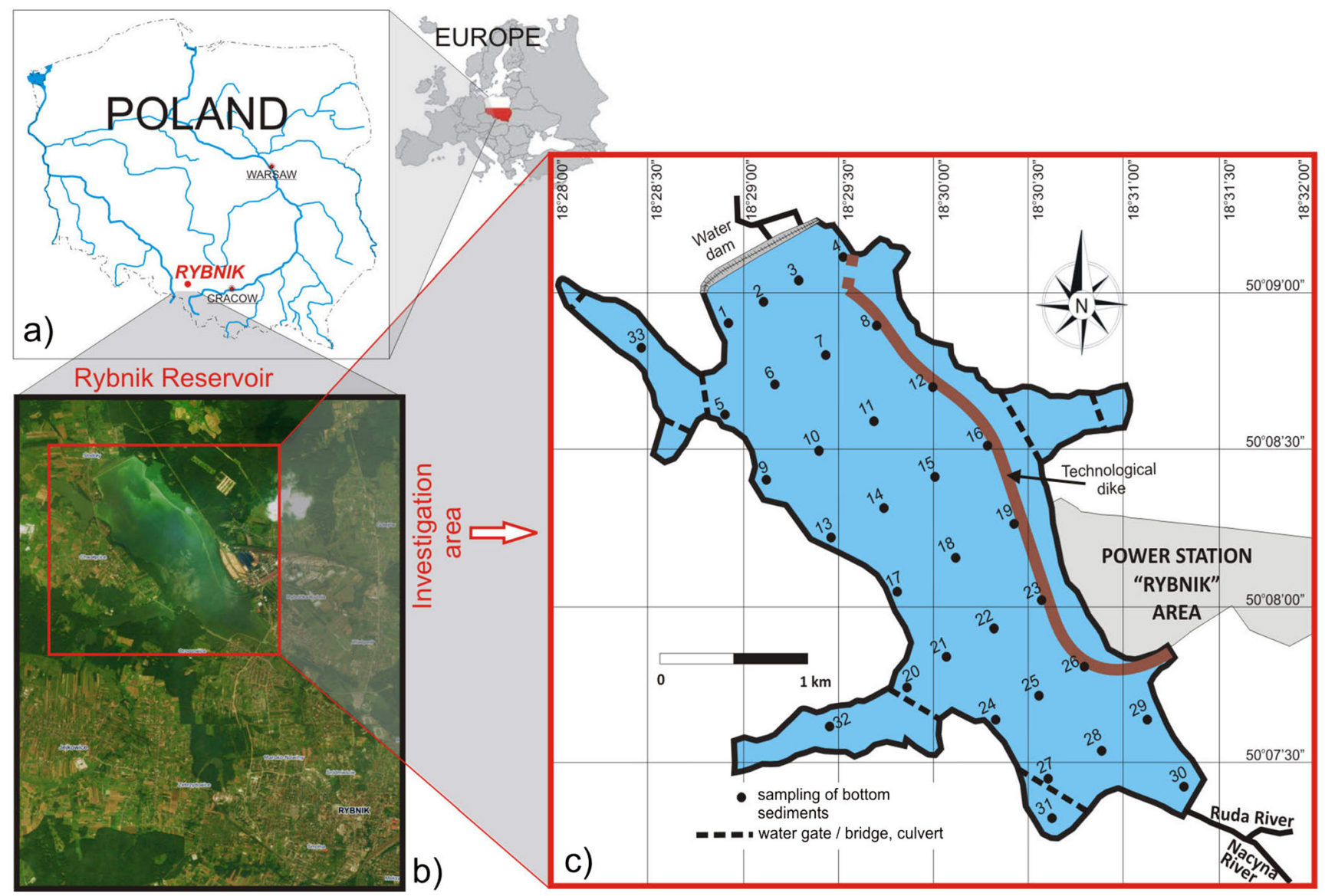

Fig. 1 Location of the research object, $\mathbf{a}$ in Poland, $\mathbf{b}$ against the background of use of the catchment, $\mathbf{c}$ location of sampling 
Rybnik Reservoir is located, together with the Nycyna, its tributary, is among the most polluted rivers in Poland. Partitioning the Ruda allowed for the creation of a major reservoir with a surface area of $4.44 \mathrm{~km}^{2}$ and a length of $4.5 \mathrm{~km}$ along with four side bays. Its depth varies between 2 and $9 \mathrm{~m}$. One spot along the western bank is remarkably deeper; the western bank is cut off with a technical dike providing water to the power plant. The location of the reservoir in an industrial area, coupled with its shallow depth, long water retention time (108 days), higher temperature and hydraulic loading, provides strong anthropopression (Baran and Tarnawski 2015; Kostecki et al. 2017).

When planning the monitoring network, the main focus was in the main part of the reservoir influenced by the Ruda River, as well as the direct vicinity of the power plant as sources of potential pollution. Thirtythree samples were taken (30 in the main area and three in the side bays) with an Ekman grab at a sediment depth of $0-15 \mathrm{~cm}$ during a research session in July/ August 2017 (Fig. 1) (Baran et al. 2019). The sediment samples were freeze dried and sieved through a 2-mm mesh for analysis of $\mathrm{PCDD} / \mathrm{F}$ concentration (Urbaniak et al. 2014). All samples were first air-dried before being subjected to organic matter content analysis.

\subsection{Determination of PCDDs/Fs}

The sediment samples were spiked with isotopically labelled standards (Cambridge Isotopes Laboratories, USA) and extracted with toluene by Accelerated Solvent Extraction 200 Dionex at $150 \mathrm{~atm}(11 \mathrm{MPa})$ at an oven temperature of 175 ${ }^{\circ} \mathrm{C}$. Extract clean-up was performed using multilayer silica columns packed with neutral, acidic and basic silica gel. Elution was performed using $n$-hexane. The obtained extracts were further concentrated under a gentle stream of nitrogen, replacing the $n$-hexane with nonane. The identification and quantification of PCDDs/Fs were performed by highresolution gas chromatography (HRGC)/high-resolution mass spectrometry (HRMS): an HP $6890 \mathrm{~N}$ Agilent Technologies GC coupled with a high-resolution mass spectrometer (AutoSpec Ultima), using perfluorokerosene as a calibration reference (lock mass). The GC was operated in the splitless injection mode. The oven temperature protocol was $150{ }^{\circ} \mathrm{C}$ for $2 \mathrm{~min}, 20{ }^{\circ} \mathrm{C} \min ^{-1}$ to $200{ }^{\circ} \mathrm{C}(0 \mathrm{~min}), 1{ }^{\circ} \mathrm{C} \min ^{-1}$ to $220{ }^{\circ} \mathrm{C}$ for $16 \mathrm{~min}$ and $3{ }^{\circ} \mathrm{C} \min ^{-1}$ to $320{ }^{\circ} \mathrm{C}$ for 3 min. The injector temperature was $270{ }^{\circ} \mathrm{C}$. The mass spectrometer was operated under positive electron ionisation conditions: $34.8 \mathrm{eV}$ electron energy at a resolving power of 10,000 with an ion source temperature of $250{ }^{\circ} \mathrm{C}$. Helium was used as a carrier gas at a flow rate of $1.60 \mathrm{~mL} \mathrm{~min}{ }^{-1}$. The samples were quantified by isotope dilution.

\subsection{Basic properties of bottom sediments}

Total carbon (TC) and total organic carbon content (TOC) were analysed using a CNS analyser (Vario EL Cube, Elementar Analysensysteme 2013). The humus compound content ( $\mathrm{C}$ ext.) was extracted from the bottom sediments by a mixture of $0.1 \mathrm{~mol} \mathrm{dm}^{-3} \mathrm{Na}_{4} \mathrm{P}_{2} \mathrm{O}_{7}$ solution $+0.1 \mathrm{~mol} \mathrm{dm}^{-3}$ $\mathrm{NaOH}$ (Mierzwa-Hersztek et al. 2018). The extraction residue, non-hydrolysing carbon (Cnh), was calculated based on the difference between the total organic carbon content (TOC) and the amount of carbon in the extract. The dissolved organic carbon (DOC) from the samples was extracted in a sediment: water mixture, ratio $1: 10 \mathrm{v} / \mathrm{v}$, by shaking on a rotary shaker for $24 \mathrm{~h}$, centrifuging in $50 \mathrm{~mL}$ tubes at $3000 \times \mathrm{g}$ for $10 \mathrm{~min}$ and filtering through a $0.45-\mu \mathrm{m}$ membrane filter. The DOC content in the water extract was assessed using TOC analyser 1200 (Thermo Elektron). The samples of sediments were analysed in two replicates. The accuracy of the performed analyses was tested using Standard Loamy Soil (OAS) batch no. 133505 as reference material. The percentage recovery of TOC ranged from 101 to $105 \%$. The granulometric composition of the samples was determined by sieve analysis.

\subsection{Statistical and graphical analysis}

The results were presented as mean, standard deviation (SD), median, minimum and maximum values and as coefficient of variation $(\mathrm{CV} \%)$. The possible relationships between chemical and biochemical parameters in the sediments were evaluated using Pearson's correlation and principal component analysis (PCA). All statistical analyses were performed using Microsoft Excel and STATISTICA 12.5 software. Variability maps were created using Surfer 8.0 software.

\section{Results and discussion}

\subsection{Concentration and profiles of PCDDs/Fs in bottom sediments}

The concentration of total PCDDs/Fs in the studied samples ranged from 28.3 to $1171.3 \mathrm{pg} \mathrm{g}^{-1}$, with TEQ values ranging

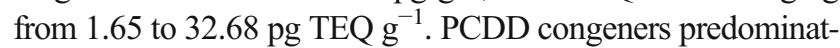
ed in the samples, ranging from 17.0 to $937.1 \mathrm{pg} \mathrm{g}^{-1}$, with a mean value of $398.2 \mathrm{pg} \mathrm{g}^{-1}$; however, the mean concentration of the sum of 10 PCDF congeners was $113.6 \mathrm{pg} \mathrm{g}^{-1}$, ranging from 11.1 to $234.2 \mathrm{pg} \mathrm{g}^{-1}$. Median concentrations were less diverse, being 160.4 for PCDDs and $119.5 \mathrm{pg} \mathrm{g}^{-1}$ for PCDFs (Table 1). Among all PCDDs/Fs in the sample, OCDD was found to have the highest percentage content, ranging from 42 to $74 \%$ (Fig. 2), with mean values of $64 \%$ observed in samples

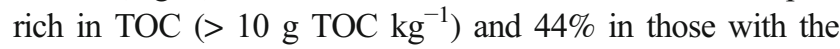
lowest TOC $\left(<10 \mathrm{~g} \mathrm{TOC} \mathrm{kg}^{-1}\right)$. Other congeners constituted 
Table 1 Concentration of PCDDs/PCDFs in the bottom sediments

\begin{tabular}{lllll}
\hline Parameters $\left(\mathrm{pg} \mathrm{g}^{-1}\right)$ & Mean $\pm \mathrm{SD}$ & Median & Range & CV\% \\
\hline PCDDs & 398.2 & 160.4 & $17.0-937.1$ & 94 \\
PCDFs & 113.6 & 119.5 & $11.1-234.2$ & 73 \\
LPCDDs + PCDFs & 511.8 & 374.7 & $28.3-1171.3$ & 86 \\
WHO-TEQ & 13.52 & 0.17 & $1.65-32.68$ & 83 \\
HQ & 0.63 & 0.52 & $0.08-1.52$ & 83 \\
\hline
\end{tabular}

a much lower share of total PCDD/F content, ranging from $0 \%$ for TCDD to $17 \%$ for $\sum$ HpCDFs. Interestingly, OCDF and $\sum \mathrm{HpCDFs}$ represented the second highest contributors to TOC content in sediment with low TOC content $(<10 \mathrm{~g}$ TOC $\mathrm{kg}^{-1}$ ), while HpCDD was found to be the second highest in the

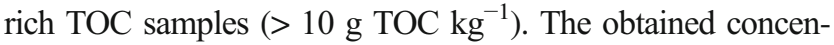
trations are within the values noted in other studies; for example, Urbaniak et al. (2015) report PCDD/F concentrations in the range of $12.27-1636.23 \mathrm{pg} \mathrm{g}^{-1}$ and TEQ from 0.72 to $21.51 \mathrm{pg}$ TEQ $\mathrm{g}^{-1}$, in small urban reservoirs, with the share of OCDD ranging from $44 \%$ to as high as $94 \%$ among the studied samples. In addition, Siebielec et al. (2019) identified much higher $\mathrm{PCDD} / \mathrm{F}$ content in sediments from an urban reservoir $(2173 \mathrm{pg}$ $\mathrm{g}^{-1}$ and $8.82 \mathrm{pg}$ TEQ $\mathrm{g}^{-1}$ ) than in one from a prevailing agricultural catchment, i.e. the Sulejowski Reservoir (17.49 to

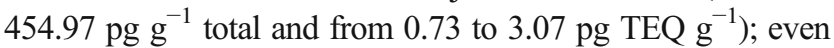
so, the urban reservoir still demonstrated a strong predominance of PCDDs and an elevated percentage content of OCDD (Urbaniak et al. 2010). By comparison, PCDD/F concentrations in the sediments of rivers, lakes and canals in the Netherlands were found to range from 1 to $10 \mathrm{pg}^{\mathrm{TEQ}} \mathrm{g}^{-1}$ (Buckley-Golder et al. 1999). A similar concentration (10.45 pg TEQ $\mathrm{g}^{-1}$ ) has been found in the Wloclawek Reservoir, Poland (Niemirycz et al. 2003). Much higher values have been noted in freshwater sediments of the Ebro River collected from the vicinity of chlorine and caustic soda production plants (189 pg TEQ $\mathrm{g}^{-1}$ ) (Eljarrat et al. 2008).
In general, $\mathrm{PCDD} / \mathrm{F}$ concentrations in freshwater sediments in EU member states typically range from $<1$ to 200 pg TEQ g ${ }^{-1}$ (Addeck et al. 2014). Marine sediments, in turn, demonstrate lower PCDD/F concentrations: from 0.97 to $64 \mathrm{pg} \mathrm{TEQ} \mathrm{g}^{-1}$ in the Gulf of Bothnia, from 14.2 to $25 \mathrm{pg}$ TEQ $\mathrm{g}^{-1}$ in the Gulf of Finland and from 0.8 to $82.2 \mathrm{pg}^{\text {TEQ }} \mathrm{g}^{-1}$ along the Swedish coast (Gómez-Lavín et al. 2011). Outside Europe, PCDD/F content in the sediments from three industrial areas in Cairo, Egypt, was found to range between 1.8 and 38 pg TEQ g $^{-1}$ (El-Kady et al. 2007), while values an order of magnitude higher have been found in sediments from industrialised areas in Homebush Bay, Australia (380 pg TEQ $\mathrm{g}^{-1}$ ) (Birch et al. 2007). Sediments from the Detroit River and Lower Rouge River in the USA have demonstrated TEQ values ranging from 4 to $62 \mathrm{pg}^{\mathrm{TEQ}} \mathrm{g}^{-1}$ (Kannan et al. 2001), while PCDD/F contents in sediment from small dam reservoirs in Nothern Taiwan ranged from 0.95 to $14.4 \mathrm{pg}$ TEQ $\mathrm{g}^{-1}$ (Chi et al. 2007). These findings indicate the concentration of PCDDs/Fs can vary significantly in bottom sediments based on a range of factors, such as the location of the given water body, its size and type of catchment land use.

\subsection{Ecological risk assessment}

The obtained $\mathrm{PCDD} / \mathrm{F}$ concentrations can be considered as high according to the sediment quality guidelines (SQG). According to the SQG, sediments containing amounts higher than $0.85 \mathrm{pg}^{\mathrm{T}} \mathrm{EQ} \mathrm{g}^{-1}$ are regarded as polluted, while those exceeding the probable effect level (PEL) level of $21.5 \mathrm{pg}$ TEQ $\mathrm{g}^{-1}$ are likely to have adverse effects (Nie et al. 2013). Based on these guidelines, the studied sediments exceeded the sediment pollution limit 2-fold to even 38-fold, indicating a high pollution level. The potential risk to organisms associated with the concentration of PCDDs/Fs in the sediments was assessed using the hazard quotient (HQ) (Table 2) (Tarnawski and Baran 2018). The HQ was calculated based on the ratio
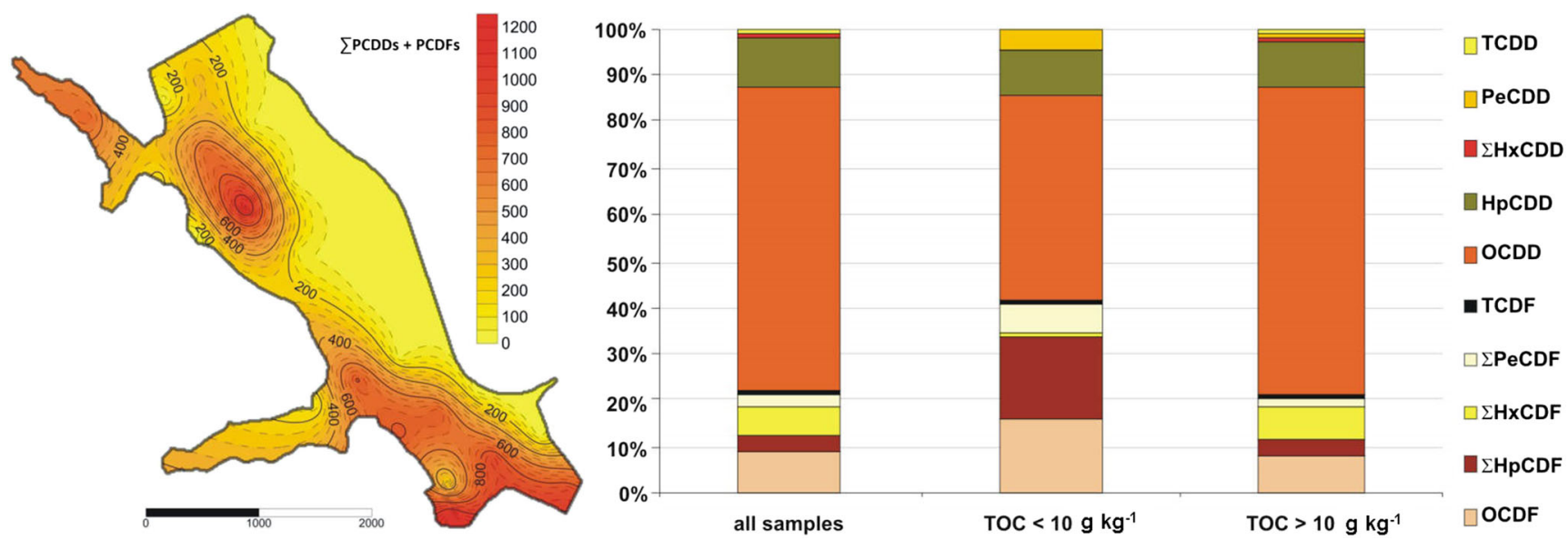

Fig. 2 Spatial distribution of $\sum$ PCDDs/Fs $\left(\mathrm{pg} \mathrm{g}^{-1}\right)$ and percentage profile of PCDD and PCDF congeners pattern in bottom sediments of the Rybnik Reservoir 
Table 2 Organic matter fraction content in the bottom sediments

\begin{tabular}{lllll}
\hline Parameters & $\begin{array}{l}\text { Mean } \pm \mathrm{SD} \\
\mathrm{g} \mathrm{kg}^{-1} \text { d.m. }\end{array}$ & Median & Range & $\mathrm{CV} \%$ \\
\hline $\mathrm{TC}^{1}$ & $54.5 \pm 53.4$ & 29.3 & $2.32-174$ & 99 \\
$\mathrm{TOC}^{2}$ & $51.6 \pm 52.5$ & 26.3 & $2.04-166$ & 102 \\
$\mathrm{Cext}^{3}$ & $12.3 \pm 10.6$ & 7.52 & $1.72-35.3$ & 86 \\
$\mathrm{Cnh}^{4}$ & $39.3 \pm 42.7$ & 18.79 & $0.08-143$ & 109 \\
$\mathrm{DOC}^{5}$ & $0.44 \pm 0.43$ & 0.17 & $0.07-1.29$ & 100 \\
\hline
\end{tabular}

${ }^{1}$ Total carbon

${ }^{2}$ Total organic carbon

${ }^{3}$ Carbon in the extract

${ }^{4}$ Non-hydrolysing carbon

${ }^{5}$ Dissolved organic carbon

between the TEQ values in each individual sample and the concentration to its corresponding PEL value-21.5 pg TEQ $\mathrm{g}^{-1}$. If $\mathrm{HQ}>1$, frequent adverse ecological effects are expected. The mean HQ ranged from 0.08 to 1.52 . The highest HQ values were found in the rich TOC samples $(>10 \mathrm{~g}$ TOC $\mathrm{kg}^{-1}$ ), while the low TOC samples demonstrated a low potential risk to the benthic fauna $(\mathrm{HQ}<1)\left(<10 \mathrm{~g} \mathrm{TOC} \mathrm{kg}^{-1}\right)$. The HQ values suggested that $67 \%$ of the sediment samples exhibited low ecological risk originating from $\mathrm{PCDD} / \mathrm{F}$ pollution and a serious risk from $23 \%$ of the samples.

\subsection{Possible sources of PCDDs/Fs in bottom sediments}

PCDDs dominated in the bottom sediments, constituting 59$78 \%$ of the total $\mathrm{PCDD} / \mathrm{F}$ concentration, while the PCDFs accounted for $22-41 \%$. Moreover, OCDD was the main congener and occupied $70-100 \%$ of PCDDs, followed by HpCDD amounting for 11-18\% (Fig. 2). Similar results were reported in the studies of other authors (Lee et al. 2006; Waszak and Dąbrowska 2009; Nieuwoudt et al. 2009; Chen et al. 2013; Nie et al. 2013; Lewnadowski et al. 2014). The high share of OCDD and HpCDD in the total PCDDs/Fs could be associated with atmospheric input from a variation of combustion process and the historical use of sodium pentachlorophenate as a wood preservative, herbicide, fungicide, bactericide, algaecide, snail cider and insecticide in the study area (Lee et al. 2006; Li et al. 2012; Nie et al. 2013). Urbaniak et al. (2013) highlight the role of industrial and domestic effluents, spills and other factors as the main sources of elevated concentrations of PCDDs/Fs in urban reservoir sediments, with a particular emphasis on the effects of atmospheric deposition and further scouring of deposited PCDDs/ Fs during rains (storm water runoff). The presence of a high percentage of PCDFs with an elevated content of $\sum \mathrm{HpCDFs}$ can be related to the impact of road transport in the area of the Rybnik Reservoir. Hagenmaier et al. (1990), Geueke et al. (1999) and Ryan and Gullett (2000) attribute elevated proportions of PCDFs to emission from diesel engines; similarly, Urbaniak et al. (2012) also report elevated concentrations of PCDFs, especially $\sum \mathrm{HpCDFs}$, in river water samples collected near a busy street. Nie et al. (2013) suggested that $\sum$ HpCDFs may also act as indicator congener for chlorophenol production. Other authors have associated high TCDD, TCDF, PeCDF and OCDF content with the production of vinyl chloride and paper pulp bleaching, and the presence of higher levels of PCDFs than PCDDs with pollution from iron metallurgy and the steel industry (Nieuwoudt et al. 2009; Louchouarn et al. 2018. Nieuwoudt et al. (2009) report that cement kilns and sinter plants are strong sources of $\mathrm{OCDD} / \mathrm{F}$ and $\mathrm{HpCD} / \mathrm{Fs}$. In the present study, OCDDs (44\%) were found to be the main congeners in sediment samples with a low TOC content $\left(<10 \mathrm{~g} \mathrm{TOC} \mathrm{kg}^{-1}\right)$, followed $\sum \mathrm{HpCDFs}$ $(17 \%)$ and OCDF (16\%).

In view of this, the PCDDs/Fs found in the Rybnik Reservoir, especially those in the central and the right, eastern, parts may be derived from a variety of sources, such as various combustion and high-temperature processes, wastewater discharges and thermal electricity generation. However, the relatively high concentrations of OCDD and HpCDD found in the samples suggest that the main sources were atmospheric deposition from various industrial processes or the combustion of coal, solid urban waste, domestic waste and wood. As already mentioned above, the Rybnik Reservoir is located in the centre of the Rybnik Coal Region in Silesia, one of Poland's major industrial centres which is home to a range of industries. It is also important to note that the reservoir forms part of the technological chain of the Rybnik power plant, being an essential source of cooling water and a direct recipient of treated industrial sewage (Baran and Tarnawski 2015; Kostecki et al. 2017). The collection and disposal of technological water has resulted in the internal circulation of heavily contaminated water in the western part of the reservoir. In addition, the reservoir receives a high level of pollution consisting of incomplete combustion products from the heating of scattered houses and the operation of the power plant, with more than four million tons of hard coal being consumed in the local area per annum.

\subsection{Content of the fraction of organic matter}

It is well known that the quality and quantity of organic matter is an important factor controlling the concentration of PCDDs/ Fs in bottom sediments (Nie et al. 2013; Chen et al. 2013; Kukučka et al. 2015; Louchouarn et al. 2018). The TC content in bottom sediments of the Rybnik Reservoir vary greatly between 2.32 and $174 \mathrm{~g} \mathrm{~kg}^{-1}$ d.m, with a mean content of $54.5 \mathrm{~g} \mathrm{~kg}^{-1}$ d.m. (Table 2). The TOC content was similar to the TC content, with a mean value of $51.6 \mathrm{~g} \mathrm{~kg}^{-1} \mathrm{~d} . \mathrm{m}$., but was highly varied $(\mathrm{CV}=102 \%)$. However, in the sediments, humic substances play an important role in the sorption, 
distribution and transport of POPs (Staniszewska et al. 2016; Baran et al. 2019). The content of $\mathrm{C}$ ext $\left(\sum \mathrm{Cha}+\mathrm{Cfa}\right)$ in the sediment samples ranged from 1.72 to $35.3 \mathrm{~g}$ and $\mathrm{Cnh}$ (C nonhydrolysing) from 0.08 to $143 \mathrm{~g} \mathrm{~kg}^{-1}$ d.m., while the extracted $\mathrm{C}$ accounted for $21-72 \%$ of the TOC (mean $24 \%$ ) and $\mathrm{Cnh}$ for about $4-86 \%$ (mean $76 \%$ ). The DOC content in the bottom sediments ranged from 0.07 to $1.29 \mathrm{~g} \mathrm{~kg}^{-1} \mathrm{~d} . \mathrm{m}$. (Table 2). It should also be emphasised that all fractions of organic matter demonstrated significantly different relative abundances $(\mathrm{CV} \%=$ from 89 to 109$)$ in the bottom sediments. The lowest TC, TOC, Cext, Cnh and DOC contents were observed in the sediments in the central and right-bank part of the reservoir, and the highest around the left, i.e. western, bank (Fig. 3). This distribution of the organic fractions and the PCDDs/Fs discussed above may be due to the uneven depth of the reservoir with regard to both its longitudinal and transverse profiles: the depth is approximately $1.5 \mathrm{~m}$ (intel zone), 3-4 m (middle zone) and 7-8 $\mathrm{m}$ (dam zone) in the central part and along the right bank, and approximately $3 \mathrm{~m}$ (inlet zone), 4-5 $\mathrm{m}$ (middle zone) and 8-9 (dam zone) on the left (Kostecki et al. 2017).

It is important to note that bottom sediments and organic matter demonstrate less movement in the deeper areas of the reservoir than the shallower areas; this results in greater deposition of organic matter in the deeper parts, thus contributing to a higher proportion of extracted $\mathrm{C}$ fractions in these sediments (Smal et al. 2015). In addition, the spatial distribution of organic matter is caused by the flow of discharged heated water from the power plant. In the inlet zone of the reservoir, the mixing of the water mass by the water intake and discharge
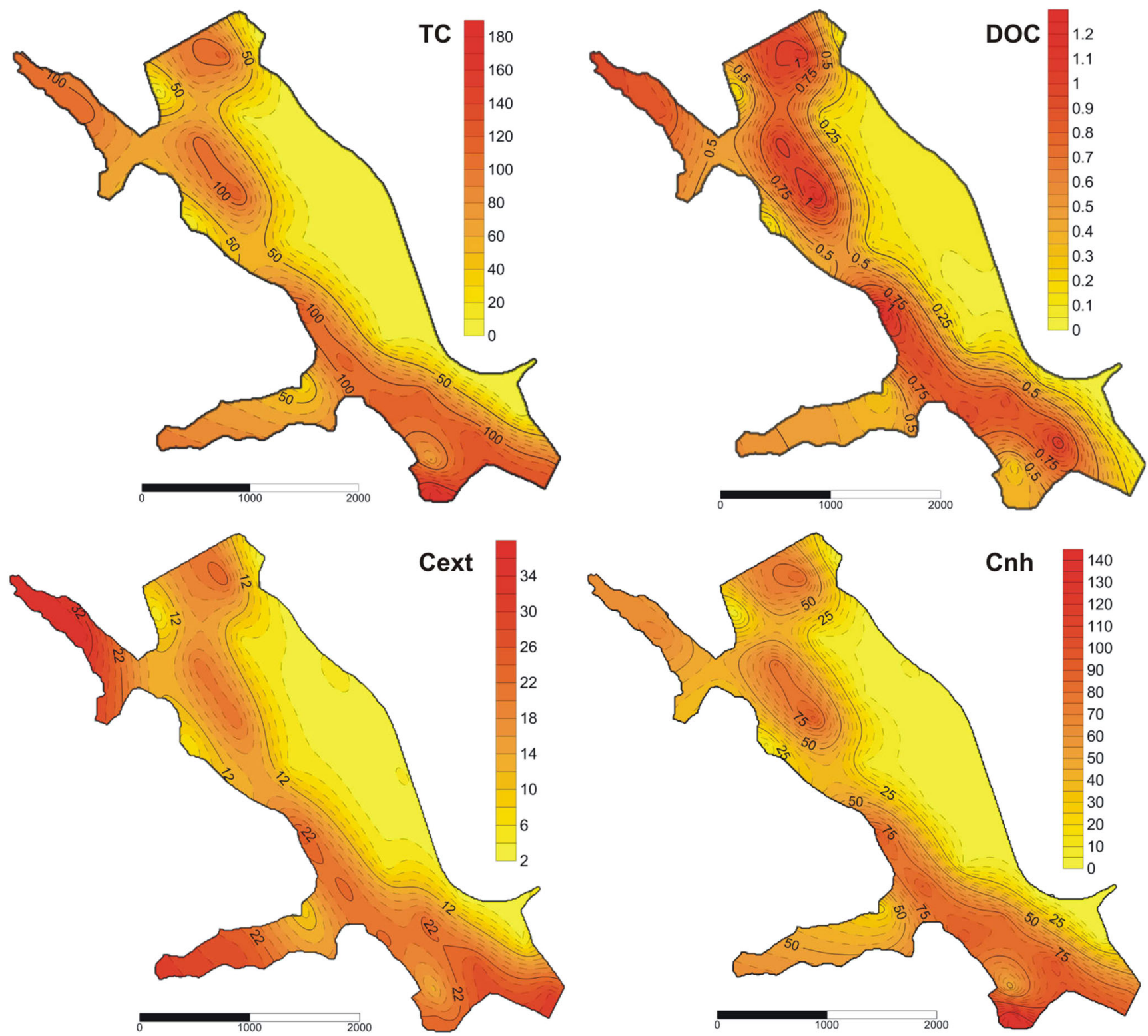

Fig. 3 Spatial distribution of TC, DOC, Cext and Cnh ( $\mathrm{g} \mathrm{kg}^{-1}$ d.m.) in bottom sediments 
from the power plant is forced by technical processes which oxygenate the water (Kostecki et al. 2017). In addition, it is likely that such movements of the heated water mass inside the reservoir accelerated the degradation of organic matter, particularly along the central part of the reservoir (Baran et al. 2019).

\subsection{Correlation between PCDDs/Fs and the organic matter fraction}

The total concentration of PCDDs/Fs, PCDDs and PCDFs has a significant positive correlation $(r=0.383-0.818)$ with TC, TOC, Cext, Cnh and DOC, which implies that organic matter plays an important role in the transport, distribution and sorption of PCDDs/Fs in the sediment of the Rybnik Reservoir (Table 3). A significant positive relationship between PCDD/F concentrations and the TOC content in bottom sediments has been noted in previous studies (Lee et al. 2006; Nie et al. 2013; Čnka et al. 2014; Gao et al. 2015). However, a strong and medium correlation for PCDFs was observed in the present study ( $r=0.704$ DOC -0.818 Cext), as well as a low and medium correlation for PCDDs $(r=0.383$ DOC -0.683 $\mathrm{Cnh}$ ), suggesting greater binding of PCDFs by organic matter.

In addition, the analysed organic matter fractions demonstrated slightly different abilities to bind PCDDs/Fs (Table 3). Non-hydrolysable carbon (Cnh) and black carbon (BC) are known to be responsible for the sorption of different organic pollutions in sediments, and this better explains the variation of organic pollutant concentrations in sediments than TOC (Peolis and Kukkonen 1997; Lohmann et al. 2005; Ghosh 2007; Tanaka et al. 2015; Staniszewska et al. 2016; Louchouarn et al. 2018). In the present study, the highest correlation coefficients were observed between PCDDs and PCDFs and humic substances (Cext and Cnh). Humic substances are capable of ionic, donor-acceptor and hydrophobic bonding, so they can bind POPs in non-toxic and nonbioavailable humic complexes (Otaka et al. 2005; Perminova et al. 2006; Tanaka et al. 2015).
However, other experimental results suggest that the concentrations of $\mathrm{PCDDs} / \mathrm{Fs}$ in sediments are not all dependent on TOC (Ikenaka et al. 2005; Lee et al. 2006; Pan et al. 2010; Nunes et al. 2011; Li et al. 2012; Eichbaum et al. 2016). Li et al. (2012) report a poor correlation between PCDDs/Fs and TOC in bottom sediments, indicating that they are influenced by seasonal changes, while Vảcha et al. (2011) note a weak correlation between POP concentration and the content and quality of organic matter in sediment. In addition, PCDD/F levels have been found to be as much as 16-fold higher in silt and clay particles than in sand or coarse particles (Lee et al. 2006). In the present study, a significant, strong correlation was observed between PCDD/F content and the proportion of the silt and clay fraction (amounting to $0-52 \%$ of the sediment), but a significant negative correlation for $\mathrm{PCDDs} / \mathrm{Fs}$ and the proportion of the sand fraction (48-100\%) (Table 3). In addition, $\mathrm{PCDD} / \mathrm{F}$ content demonstrated a higher correlation coefficient with the proportion share of the silt and clay fractions than with TOC. Like PCDDs/Fs, the finest fractions, such as silt and clay, demonstrated higher TOC levels, probably because these possess the greatest surface area for the adsorption of organic carbon. Consequently, it is not surprising that a significant correlation $(r=0.741, \mathrm{p}<0.05)$ was found between proportion of the silt/clay fraction and the TOC content in the analysed sediments. In addition, the fact that the sand fraction predominated in the sediments from the central and right-bank part of the reservoir may explain the low concentration of PCDDs/Fs observed therein (Fig. 2). Ikenaka et al. (2005) and Lee et al. (2006) reported that the distribution of PCDDs/Fs and PAHs were also influenced by the proportion of the finest fraction, containing organic matter as the main sorbent.

PCA analysis identified two factors accounting for $92 \%$ of the variation in the total PCDD/F content in bottom sediments (Table 4). The first factor accounted for $79 \%$ of the variation and was found to be strongly correlated with PCDF and organic matter content, indicating that organic matter plays an important role in the accumulation of PCDDs/Fs in bottom sediments and an indirect role in their transport. In addition, the results would suggest that the transformation of organic matter plays a
Table 3 Correlation coefficients of dioxins content and properties of sediments

\begin{tabular}{llllllll}
\hline Parameter & $\mathrm{TC}^{1}$ & $\mathrm{TOC}^{2}$ & $\mathrm{Cext}^{3}$ & $\mathrm{Cnh}^{4}$ & $\mathrm{DOC}^{5}$ & Sand & Silt + clay \\
\hline PPCDDs/PCDFs & 0.732 & 0.709 & 0.729 & 0.736 & 0.461 & -0.895 & 0.895 \\
PCDDs & 0.677 & 0.667 & 0.672 & 0.683 & 0.383 & -0.881 & 0.881 \\
PCDFs & 0.808 & 0.734 & 0.818 & 0.803 & 0.704 & -0.750 & 0.750 \\
\hline
\end{tabular}

\footnotetext{
${ }^{1}$ Total carbon

${ }^{2}$ Total organic carbon

${ }^{3}$ Carbon in the extract

${ }^{4}$ Non-hydrolysing carbon

${ }^{5}$ Dissolved organic carbon

Values are significant at $p \leq 0.05 ; 0<r<0.3$ very low correlation; $0.3 \leq r<0.5$ low correlation; $0.5 \leq r<0.7$ medium correlation; $0.7 \leq r<0.9$ strong correlation; $0.9 \leq r<1$ very strong correlation
} 
Table 4 Principle component matrix (after varimax rotation) for variables

\begin{tabular}{lll}
\hline Variables & PCA 1 & PCA 2 \\
\hline$\sum$ PCDD/PCDFs & 0.368 & 0.901 \\
PCDDs & 0.285 & 0.923 \\
PCDFs & 0.784 & 0.486 \\
TC & 0.875 & 0.466 \\
TOC & 0.780 & 0.509 \\
Cext & 0.890 & 0.448 \\
Cnh & 0.871 & 0.473 \\
DOC & 0.915 & 0.098 \\
Sand & -0.374 & -0.894 \\
Silt + clay & 0.374 & 0.894 \\
Total variance \% & 79 & 13 \\
Cumulative variance $\%$ & 79 & 92 \\
\hline
\end{tabular}

Factor loadings exceeding 0.7 are shown in an italics

considerable role in the behaviour of PCDFs in the bottom sediments of the Rybnik Reservoir. The second factor accounted for $13 \%$ of the variation; it was strongly positively correlated with $\sum \mathrm{PCDD} / \mathrm{F}$ and $\sum \mathrm{PCDD}$ content, as well as the proportion of silt and clay, and negatively correlated with the proportion of the sand fraction (Table 4), suggesting that the finest fraction plays a dominant role in the distribution of the bottom sediments. These results also indicate that the PC2 covering the silt and clay fractions and the $\sum \mathrm{PCDDs} / \mathrm{Fs}$ and the $\sum$ PCDDs in the bottom sediment share the same sources.

The presence of fine silt particles $(2-10 \mu \mathrm{m})$ can significantly increase the bioavailability of PCDDs/Fs (Lee et al. 2006): it has been proposed that grain size could be an important factor in the distribution of PCDDs/Fs in bottom sediments (Yeager et al. 2010; Zhao et al. 2010), and many aquatic organisms take up nutrition from the finest fraction through filtering. Piskorska-Pliszczyńska et al. (2013) report higher $\mathrm{PCDF} / \mathrm{Fs}$ levels in omnivorous and carnivorous fish. In bream (Abramis brama), the mean PCDD + PCDF + PCB concentration was found to be $1.70 \pm 0.55 \mathrm{pg}^{\mathrm{TEQ}} \mathrm{g}^{-1}$ fresh mass in muscle tissue; PCDDs/Fs dominated (ca. 57\%) and accounted for $43 \%$ of concentrations allowable by EU standards. As shown in Fig. 2, the percentage profile of PCDDs and the pattern of lipophilic PCDF congeners in bottom sediments can be used as primary indicators of their sources in the aquatic system. The PC analysis confirmed the above results, and identified slightly different sources and distributions of PCDDs and PCDFs in the analysed bottom sediments.

\section{Conclusions}

1. The concentration of PCDDs/Fs in the sediments ranged from 1.65 to $32.68 \mathrm{pg} \mathrm{TEQ} \mathrm{g}^{-1}$, and their levels were 2- to 38-fold higher than SQG limit, indicating high potential ecological risk. The distribution of PCDDs/Fs in the sediments was characterised by a high share of OCDD and > HpCDD $>$ OCDF $\left(\right.$ TOC $>10 \mathrm{~g} \mathrm{~kg}^{-1} \mathrm{~d}$.m) and $>$ $\sum$ HpCDFs $>$ OCDF $\left(\right.$ TOC $<10 \mathrm{~g} \mathrm{~kg}^{-1}$ d.m.).

2. The congener profile of $\mathrm{PCDDs} / \mathrm{Fs}$ in the bottom sediments indicated that they were primarily derived by emission from the combustion processes. However, the PCDDs/Fs in the sediments also come from transport, high-temperature processes, wastewater discharges and thermal electricity generation.

3. The PCDD/F concentration significantly correlated with the presence of all fractions of organic matter, which implies that organic matter in the sediments affected PCDD/F distribution. The strongest correlation coefficients were found between PCDDs/Fs and humic substances (Cext and $\mathrm{Cnh}$ ).

4. Besides organic matter, the silt/clay fractions of the sediments were particularly important in the fate and migration of PCDDs/Fs in bottom sediments. The silt/clay fractions of bottom sediments play a dominant role in the movement of PCDDs/Fs, while the organic matter fraction affects their sorption. The results provide useful information for predicting the fates of PCDDs/Fs in the bottom sediments.

Funding information The study was financed by grant no. 2016/21/B/ ST10/02127: "Assessment of the bottom sediment organic matter on bioavailability and toxicity of chemical compounds" provided by the National Science Centre, Poland.

\section{Compliance with ethical standards}

Conflict of interest The authors declare that they have no conflict interest.

Open Access This article is distributed under the terms of the Creative Commons Attribution 4.0 International License (http:// creativecommons.org/licenses/by/4.0/), which permits unrestricted use, distribution, and reproduction in any medium, provided you give appropriate credit to the original author(s) and the source, provide a link to the Creative Commons license, and indicate if changes were made.

\section{References}

Addeck A, Croesa K, Van Langenhovea K, Denisonb MS, Elhamalawyc A, Elskensa M, Baeyen W (2014) Time-integrated monitoring of polychlorinated dibenzo-p-dioxins and polychlorinated dibenzofurans $(\mathrm{PCDDs} / \mathrm{Fs}$ ) in urban and industrial wastewaters using a ceramic toximeter and the CALUX bioassay. Chemosphere 94:27-35

Baran A, Tarnawski M (2015) Assessment of heavy metals mobility and toxicity in contaminated sediments by sequential extraction and a battery of bioassays. Ecotoxicology 24(6):1279-1293

Baran A, Mierzwa-Hersztek M, Gondek K, Tarnawski M, Szara M, Gorczyca O, Koniarz T (2019) The influence of the quantity and quality of sediment organic matter on the potential mobility and 
toxicity of trace elements in bottom sediment. Environ Geochem Health.:1-18. https://doi.org/10.1007/s10653-019-00359-7

Birch GF, Harrington C, Symons RK, Hunt JW (2007) The source and distribution of polychlorinated dibenzo-p-dioxin and polychlorinated dibenzofurans in sediments of Port Jackson, Australia. Mar Pollut Bull 54:295-308

Buckley-Golder DH et al (1999) Compilation of EU Dioxin Exposure and Health Data: summary report produced for European Commission DG Environment. Report No. AAET/EEQC/0016

Chen L, Bi Y, Zhu K, Hu Z, Zhao W, Henkelmann B, Bernhöft S, Temoka C, Schramm KW (2013) Contamination status of dioxins in sediment cores from the Three Gorges Dam area, China. Environ Sci Pollut Res Int 20(6):4268-4277

Chi KH, Chang MB, Kao SJ (2007) Historical trends of dioxin-like compounds in sediments buried in a reservoir in Northern Taiwan. Chemosphere 68:1733-1740

Čnka K et al (2014) PCDDs, PCDFs, PCBs and OCPs in sediments from selected areas in the Slovak Republic. Chemosphere 98:37-43

Eichbaum K, Brinkmann M, Nuesser L, Buchinger S, Reifferscheid G, Codling G, Jones P, Giesy JP, Hecker M, Hollert H (2016) Bioanalytical and instrumental screening of the uptake of sediment-borne, dioxin-like compounds in roach (Rutilus rutilus). Environ Sci Pollut Res 23:12060-12074

Eljarrat E, Martínez MA, Sanz P, Concejero MA, Piña B, Quirós L, Raldúa D, Barceló D (2008) Distribution and biological impact of dioxin-like compounds in risk zones along the Ebro River basin (Spain). Chemosphere 71:1156-1161

El-Kady AA et al (2007) Polychlorinated biphenyl, polychlorinated dibenzo-p-dioxin and polychlorinated dibenzofuran residues in sediments and fish of the River Nile in the Cairo region. Chemosphere 68:1660-1668

Förstner U, Hollert H, Brinkmann M, Eichbaum K, Weber R, Salomons W (2016) Dioxin in the Elbe river basin: policy and science under the water framework directive 2000-2015 and toward 2021. Environ Sci Eur 28:9. https://oi.org/10.1186/s12302-016-0075-8

Gao L, Huang H, Liu L, Li C, Zhou X, Xia D (2015) Polychlorinated dibenzo- $p$-dioxins, dibenzofurans and dioxin-like polychlorinated biphenyls in sediments from the Yellow and Yangtze Rivers, China. Environ Sci Pollut Res 22:19804-19813

Geueke KJ, Gessner A, Quass U, Bröker G, Hiester E (1999) PCDD/F emissions from heavy duty vehicle diesel engines. Chemosphere 38(12):2791-2806

Ghosh U (2007) The role of black carbon in influencing availability of PAHs in sediments. Hum Ecol Risk Assess 13(2):276-285

Gómez-Lavín S, Gorri D, Irabien Á (2011) Assessment of PCDD/Fs and PCBs in sediments from the Spanish Northern Atlantic Coast. Water Air Soil Pollut 221:287-299

Hagenmaier $\mathrm{H}$ et al (1990) Emissions of polychalogenated dibenzodioxins and dibenzofurans from combustion engines. Organohalog Compd 2:329-334

Ikenaka Y, Eun H, Watanabe E, Miyabara Y (2005) Sources, distribution, and pattern of dioxins in the bottom sediment of Lake Suw, Japan. Bull Environ Contam Toxicol 75:915-921

Kannan K, Kober JL, Kang YS, Masunaga S, Nakanishi J, Ostaszewski A, Giesy JP (2001) Polychlorinated naphtalens, -biphenyls, dibenzo-p-dioxins, -dibenzofurans, polycyclic aromatic hydrocarbons and alcylphenols in sediment from the Detroit and Rouge Rivers, Michigan, USA. Environ Toxicol Chem 20:1878-1889

Kostecki M, Tytła M, Kernert J, Stahl K (2017) Temporal and spatial variability in concentrations of phosphorus species under thermal pollution conditions of a dam reservoir - the Rybnik Reservoir case study. Arch Environ Prot 43(3):42-52

Kukučka P, Audy O, Kohoutek J, Holt H, Kalábová T, Holoubek H, Klánová J (2015) Source identification. spatio-temporal distribution and ecological risk of persistent organic pollutants in sediments from the upper Danube catchment. Chemosphere 138:777-783
Lee S-J, Ji-Hun K, Yoon-Seok C, Moon HM (2006) Characterization of polychlorinated dibenzo-p-dioxins and dibenzofurans in different particle size fractions of marine sediments. Environ Pollut 144: 554-561

Lewandowski K et al (2014) Polychlorinated dibenzo- $p$-dioxins (PCDDs), polychlorinated dibenzofurans (PCDFs) and pentachlorophenol (PCP) in bottom sediments of the Port of Gdansk. Oceanol Hydrobio St 43:312-323

Li C, Zheng M, Gao L, Liu L, Xiao K (2012) Levels and distribution of PCDD/Fs, dl-PCBs, and organochlorine pesticides in sediments form the lower reaches of the Haihe River basin, China. Environ Monit Assess 85(2):1175-1187

Lohmann R, MacFarlane J, Gschwend PM (2005) Importance of black carbon to sorption of native PAHs, PCBs, and PCDDs in Boston and New York Harbor Sediments. Environ Sci Technol 39(1):141-148

Louchouarn P et al (2018) Limited mobility of dioxins near San Jacinto super fund site (waste pit) in the Houston Ship Channel, Texas due to strong sediment sorption. Environ Pollut 238:988-998

Micheletti C, Critto A, Marcomini A (2007) Assessment of ecological risk from bioaccumulation of $\mathrm{PCDD} / \mathrm{Fs}$ and dioxin-like $\mathrm{PCBs}$ in coastal lagoon. Environ Int 33:45-55

Mierzwa-Hersztek M, Gondek K, Kopeć M, Ukalska-Jaruga A (2018) Biochar changes in soil based on quantitative and qualitative humus compound parameters. Soil Sci Ann 69(4):234-242

Nie Z, Tang Z, Zhu X, Yang Y, Fu H, Die Q, Wang Q, Huang Q (2013) Occurrence, possible sources, and temporal trends of polychlorinated dibenzo-p-dioxins and dibenzofurans in water and sediment from the lower Yangtze River basin, Jiangsu and Shanghai areas of Eastern China. Environ Sci Pollut Res 20:8751-8762

Niemirycz E., Gozdek J, Kaczmarczyk A, Tyszkiewicz H (2003) Antropogeniczne substancje organiczne: pochodzenie rozmieszczenie i oddziaływanie $\mathrm{w}$ osadach wodnych Zbiornika Włocławskiego. IMGW, raport projektu GF/POL/INV/R.22 (in Polish)

Nieuwoudt C, Quinn LP, Pieters R, Jordaan I, Visser M, Kylin H, Borgen AR, Giesy JP, Bouwman H (2009) Dioxin-like chemicals in soil and sediment from residential and industrial areas in central South Africa. Chemosphere 76:774-783

Nunes M, Marchand P, Vernisseau A, le Bizec B, Ramos F, Pardal MA (2011) PCDD/Fs and dioxin-like PCBs in sediment and biota from the Mondego estuary (Portugal). Chemosphere 83:1345-1352

Otaka H, Shinomiya M, Amagai T (2005) Extractability of dioxins from soil: II. Effects of acid or alkaline pretreatment on the extractability of dioxin homologues from soil samples. Int J Environ An Ch 85(8): $515-530$

Pan J, Yang Y, Geng C, Yeung LWY, Cao X, Dai T (2010) Polychlorinated biphenyls, polychlorinated dibenzo-p-dioxins and dibenzofurans in marine and lacustrine sediments from the Shandong Peninsula, China. J Hazard Mater 176:274-279

Peolis F, Kukkonen J (1997) Binding of organic pollutants to humic and fulvic acids: influence of $\mathrm{pH}$ and the structure of humic material. Chemosphere 34(8):1693-1704

Perminova IV et al (2006) Mediating effects of humic substances in the contaminated environments. In: Twardowska I, Allen HE, Häggblom MM, Stefaniak S (eds) Soil and water pollution monitoring, protection and remediation. NATO Science Series, vol 69. Springer, Dordrecht. https://doi.org/10.1007/978-1-4020-4728-2 17

Perminova IV, García-Mina JM, Knicker H, Miano T (2019) Humic substances and nature-like technologies. J Soils Sediments 19: 2663-2664

Piskorska-Pliszczyńska J, Mikołajczyk S, Maszewski S, Warenik-Bany M, Baran M (2013) The content of dioxins in fish from the selected polish water reservoirs. Proceedings of ECOpole 7(2):685-693

Roumak VS, Levenkova ES, Vladimir NV, Popov V, Turbabina K, Shelepchikov A (2018) The content of dioxins and furans in soils, 
bottom sediments of water bodies, and tissues of small mammals near the landfill site with municipal solid wastes (Moscow, Russia). Environ Sci Pollut Res 25:29379-29386

Ryan JV, Gullett BK (2000) On-road emission sampling of a heavy-duty diesel vehicle for polychlorinated dibenzo-p-dioxins and polychlorinated dibenzofurans. Environ Sci Technol 34(21):44834499

Siebielec S, Siebielec G, Urbaniak M, Smerczak B, Grzęda E, Wyrwicka A, Kidd P (2019) Impact of rhizobacterial inoculants on plant growth and enzyme activities in soil treated with contaminated bottom sediments. Int J Phytoremediat 21(4):325-333

Smal H, Ligęza S, Baran S, Wójcikowska-Kapusta A (2015) Quantity and quality of organic carbon in bottom sediments of two upland dam reservoirs in Poland. Environ Prot Eng 41(1):95-110

Staniszewska M, Koniecko I, Falkowska L, Burska D, Kiełczewska J (2016) The relationship between the black carbon and bisphenol A in sea and river sediments (Southern Baltic). J Environ Sci (China) 41:24-32

Tanaka F, Fukushima M, Kikuchi A, Yabuta H, Ichikawa H, Tatsumi K (2015) Influence of chemical characteristics of humic substances on the partition coefficient of a chlorinated dioxin. Chemosphere 58(10):1319-1326

Tarnawski M, Baran A (2018) Use of chemical indicators and bioassays in bottom sediment ecological risk assessment. Arch Environ Con Tox 74:395-407

Urbaniak M, Zieliński M, Ligocka D, Zalewski M (2010) A comparative analysis of selected persistent organic pollutants (POPs) in reservoirs of different types of anthropopression - Polish and Ethiopian studies. Fresen Environ Bull 19:2710-2719

Urbaniak M, Skowron A, Zieliński M, Zalewski M (2012) Hydrological and environmental conditions as key drivers for spatial and seasonal changes in PCDD/PCDF concentrations, transport and deposition along urban cascade reservoirs. Chemosphere 88(11):1358-1367

Urbaniak M, Zieliński M, Kaczkowski Z, Zalewski M (2013) Spatial distribution of PCDDs. PCDFs and dl-PCBs along the cascade of urban reservoirs. Hydrol Res 44(4):614-630

Urbaniak M, Kiedrzyńska E, Zieliński M, Tołoczko W, Zalewski M (2014) Spatial distribution and reduction of PCDD/PCDF toxic equivalents along three shallow lowland reservoirs. Environ Sci Pollut Res 21:4441-4452

Urbaniak M, Zieliński M, Wagner I (2015) Seasonal distribution of PCDDs/PCDFs in the small urban reservoirs. Int J Environ Res 9(2):745-752

Vácha R, Čechmánková J, Skála J, Hofman P, Čermák M, Sáňka T, Váchová T (2011) Use of dredged sediments on agricultural soils from viewpoint of potentially toxic substances. Plant Soil Environ 57(8):388-395

Waszak I, Dąbrowska H (2009) Persistent organic pollutants in two fish species of Percidae and sediment from the Sulejowski Reservoir in central Poland. Chemosphere 75(9):1135-1143

Yeager K, Brinkmeyer R, Rakocinski C, Schindler K, Santschi P (2010) Impacts of dredging activities on the accumulation of dioxins in surface sediments of the Houston Ship Channel, Texas. J Coast Res 26(4):743-752

Zhao X, Zheng B, Qin Y, Jiao L, Zhang L (2010) Grain size effect on $\mathrm{PBDE}$ and $\mathrm{PCB}$ concentrations in sediments from the intertidal zone of Bohai Bay, China. Chemosphere 81(8):1022-1026

Publisher's note Springer Nature remains neutral with regard to jurisdictional claims in published maps and institutional affiliations. 